\title{
Bevordering van de interculturele competentie van studenten in vertaalcolleges aan de Katholieke Johannes Paulus II Universiteit te Lublin
}

\author{
MURIEL WATERLOT \\ John Paul II Catholic University of Lublin \\ Katedra Literatury i Języka Niderlandzkiego \\ Katolicki Uniwersytet Lubelski Jana Pawła II \\ Al. Racławicka 14, C-945 \\ 20-950 Lublin, Poland \\ murielwaterlot@kul.pl
}

\section{Fostering Intercultural Competence of Students during Translation Classes at the John Paul II Catholic University of Lublin}

\begin{abstract}
Intercultural communication has become a scientific discipline which aims at improving communication during intercultural contacts by means of fostering the intercultural awareness and competence of the interlocutors involved within the intercultural communication process.

In view of the intensifying European and international contacts the interest for this competency has grown during the last decades. This can among others be observed within foreign language teaching, but also in the training of translators at university level where new didactical approaches and teaching methods are being developed in order to improve the intercultural of future translators.

This article presents a preliminary collaboration between the John Paul II Catholic University of Lublin and non-profit organization of translators, as well as the theoretical and practical backgrounds of a project which that they envisage to realize in future in order to transform its participants into intercultural competent translators.
\end{abstract}

Keywords: didactics of translation; functional approach; intercultural competence; training of translators 


\section{Inleiding}

In Europa is de belangstelling voor interculturele competentie sterk toegenomen als gevolg van de culturele en sociale complexiteit betrokken bij het Europees burgerschap, waarbij een brede waaier aan talen en culturen betrokken raakte die met elkaar samenleven en op verschillende niveaus met elkaar interageren. Dit verschijnsel veroorzaakte een verschuiving van een etnocentrisch naar een interactief gedragspatroon op basis waarvan relaties tussen verschillende culturen worden opgebouwd. Deze houding beïnvloedde tevens de pedagogische aanpak in het onderwijs die niet langer focust op kennis maar op de leerder en zijn of haar competenties. Het Gemeenschappelijk Europees Referentiekader voor Talen (ERK) heeft een cruciale rol gespeeld in deze evolutie, omdat het pleit voor een actiegerichte benadering van het (taal)onderwijs, wat erop neerkomt dat het leerproces vooral beoogt leerders voor te bereiden op een actief taalgebruik voor communicatieve doeleinden op individueel en maatschappelijk gebied:

De hier gekozen benadering is actiegericht in die zin dat gebruikers en leerders van talen in de eerste plaats worden beschouwd als 'sociale wezens' [...] (Meijer en Noijons 2008: 13)

Taalgebruik, met inbegrip van taalleren, omvat de handelingen die worden verricht door mensen die individueel en als sociale wezens een reeks algemene competenties en meer in het bijzonder communicatieve taalcompetenties ontwikkelen. (Meijer en Noijons 2008: 13)

Dezelfde verschuiving merken we op in de didactiek van de vertaling waar naast de traditionele aanpak - waar vertalen synoniem is met de reproductie of weergave van een tekst in een andere taal - we te maken krijgen met de opkomst van de zogenaamde functionele aanpak waar vertalen een complexe betekenis krijgt en wordt aangezien als de productie van een doeltekst die in de context van een doelcultuur kan functioneren voor ontvangers van deze doelcultuur. Vanuit deze didactische optiek wordt vertalen beschouwd als een interculturele communicatieve handeling en niet langer als een loutere 'taalkundige oefening' waarbij minimale taaleenheden vanuit een brontaal naar een doeltaal worden getransponeerd. Met andere woorden zal bij een dergelijke aanpak een vertaaloefening niet worden beschouwd als een louter taalkundige oefening waar de nadruk ligt op het verwerven van een bottom-up-vaardigheid en op het begrip van specifieke vormen en de inhoud van een brontekst en het vertalen ervan - in een min of meer lineaire keten - in een taalkundig 'equivalente' doeltekst:

[...] translation has traditionally been treated as a matter of acquiring a bottom-up skill in understanding source text forms and their content and transforming them in a more or less linear sequence into linguistically 
'equivalent' target text forms: the content is considered as the invariable in this operation and equivalence is roughly equated with contextbound dictionary 'meanings' [...] (Vermeer 1998: 61)

Deze nieuwe aanpak heeft ervoor gezorgd dat aan Europese universiteiten nieuwe methoden geëxploreerd worden die beogen om tijdens vertaalcolleges de interculturele competentie en communicatie van studenten te bevorderen. Een voorbeeld hiervan is de hiertoe opgerichte onderzoeksgroep PACTE ${ }^{1}$ van de Universiteit van Barcelona en het EU-project PICT (Promoting Intercultural Competence in Translators): een samenwerkingsproject tussen universiteiten van West- en Centraal Europa dat in 2011-2013 werd gerealiseerd en tot doel had een 'toolkit' uit te werken voor het introduceren van interculturele communicatie in vertaalprogramma's van het universitair en hoger onderwijs. Ook onze universiteit, de Katholieke Johannes Paulus II Universiteit te Lublin, werkt aan de ontwikkeling van deze competentie in haar vertaalcolleges aan de hand van een samenwerkingsproject met een vereniging van vertalers (zie punt 4 voor verdere details).

Voordat ik overga tot het presenteren van de theoretische en praktische aspecten van dit project zelf (zie punt 3), zal ik eerst de begrippen vertaalcompetentie en interculturele competentie definiëren en nagaan hoe ze zich tegenover elkaar kunnen verhouden. Daarna zal ik de componenten van beide begrippen nader omschrijven. Na de presentatie van het project zelf zal ik tot slot in de conclusie de meerwaarde van het project uiteenzetten.

\section{Vertaalcompetentie - interculturele competentie}

\subsection{Vertaalcompetentie}

Volgens Antony Pym (2003: 482) zijn de definities van vertaalcompetentie uiterst heterogeen. Enerzijds hebben we de academici die het bestaan ervan volledig ontkennen - zoals Wolfram Wilss (1976: 119) die het volgende beweert: "[...] translational competence as a uniform qualification for translational work is, to all intents and purposes, nonexistent and probably also nondefinable."

Anderzijds treffen we geleerden aan die de vertaalcompetentie als een vage 'hypercompetentie' beschouwen met een waaier aan onderdelen (Pym 2003: 485).

\footnotetext{
${ }^{1}$ De PACTE-onderzoeksgroep (PACTE is een Spaans letterwoord dat staat voor Proces in de Verwerving van Vertaalcompetentie en Evaluatie) werd opgericht in oktober 1997 en beoogt het onderzoek naar de verwerving van vertaalcompetentie in schriftelijke vertalingen naar en vanuit een vreemde taal. Alle leden van de onderzoeksgroep zijn vertalers en docenten vertaling die professionele vertalers opleiden de Facultat de traducció i d'Interpretació (Faculteit voor vertalen en tolken) van de Universitat Autónoma de Barcelona. (http://grupsderecerca.uab.cat/pacte/en, geraadpleed op 23.05.2015).
} 
Tussen deze twee extreme standpunten, kunnen we een aantal trends identificeren. Een van die trends opteert voor een multicomponentiële en interdisciplinaire benadering van vertaalcompetentie waar ook culturele, technologische en professionele aspecten deel van uitmaken (o.a. Bell 1991; Beeby 2000; Eyckmans en Segers 2010). Dit model met een eindeloos aantal onderdelen wordt bekritiseerd door Pym die beweert dat het uitsluitend door institutionele belangen wordt gedreven en het niet in staat is om gelijke tred te houden met het tempo van de veranderingen in de technologische en professionele veranderingen (Pym 2003: 482). Hij stelt de 'mininalist approach' voor en definieert vertaalcompetentie als de bekwaamheid om een reeks van meerdere geschikte doelteksten voort te brengen voor een toepasselijke brontekst, gevolgd door het vermogen om uit deze reeks één enkele geschikte doeltekst te selecteren (Pym 2003: 489). Deze kijk benadrukt het belang van de interactie als een fundamenteel onderdeel van de vertaalcompetentie.

Uit de vele modellen die er bestaan voor de omschrijving van de vertaalcompetentie die geconstrueerd zijn op basis van wetenschappelijke bevindingen van academici en als blauwdruk gebruikt worden bij het ontwerpen van vertaalcursussen, selecteerde ik het multicomponentieel model van de PACTE-onderzoeksgroep (Process of Acquisition of Translation Competence and Evaluation) dat werd ontwikkeld door Allison Beeby (2000). Ik opteerde voor dit model omdat we hierin te maken hebben met een dynamische kijk op de vertaalcompetentie: afhankelijk van de context, kan een bepaalde subcompetentie een min of meer centrale plaats innemen. Deze kijk op vertaalcompetentie houdt ook in dat de vertaalcompetentie uitsluitend kan worden verworven als alle onderliggende competenties geactiveerd worden (zie 2.4. voor meer uitleg over dit model en haar subcompetenties).

\subsection{Interculturele competentie}

In de Delphi Study ${ }^{2}$ (Deardorff 2006) samengesteld uit een panel van 23 internationaal bekende interculturele experts, wordt interculturele competentie in de hoogst gerankte definitie als volgt omschreven: "The ability to communicate effectively and appropriately in intercultural situations based on one's intercultural knowledge, skills and attitudes" (Deardorff 2008: 33). Uit Deardorff's definitie kunnen we opmaken dat kennis, vaardigheden en houdingen een essentiële rol te vervullen hebben bij het waarborgen van een doeltreffende en adequate communicatie in interculturele situaties.

\footnotetext{
${ }^{2}$ De Delphi Study is een studie die in 2004 werd gerealiseerd door Darla K. Deadorff met als doel het begrip interculturele competentie te definiëren. Hiervoor werden 23 vooraanstaande experts in interculturele communicatie bevraagd, waaronder Michael Byram, Janet Bennett en Guo-Ming Chen (Deardorff 2008: 41).
} 
$\mathrm{Nu}$ we de begrippen vertaalcompetentie en interculturele competentie hebben gedefinieerd, wordt in punt 2.3. nagegaan hoe beide begrippen zich tegenover elkaar kunnen verhouden.

\subsection{Verhouding vertaalcompetentie - interculturele competentie: mogelijke scenario's}

Om de relatie tussen vertaalcompetentie en interculturele competentie te omschrijven, kunnen we beroep doen op een aantal mogelijke configuraties tussen beide begrippen. Enerzijds kunnen we ervan uitgaan dat er geen hiërarchisch verband bestaat tussen beide competenties en dat ze zich beide op hetzelfde niveau bevinden. Anderzijds kan worden verondersteld dat de vertaalcompetentie bestaat uit een reeks van subcompetenties waaronder de interculturele competentie. Deze configuratie verwijst naar de in punt 2.1. aangehaalde multicomponentiële en interdisciplinaire benadering van de vertaalcompetentie die onder meer door Alison Beeby (2000) is vooropgesteld. Een derde en laatste mogelijke configuratie is een zuiver theoretische, waarbij de vertaalcompetentie een onderdeel is van de interculturele competentie die als overkoepelende competentie fungeert.

In de context van dit onderzoek lijkt de tweede configuratie de meest geschikte, wat erop neerkomt dat vertaalcompetentie uitsluitend kan worden verworven als alle onderliggende competenties of competenties waaruit deze is samengesteld, geactiveerd worden. Dit betekent dat als er een leemte ontstaat in één van deze onderliggende of subcompetenties, de vertaalcompetentie gebrekkig zal zijn.

Afhankelijk van de context, kan een bepaalde subcompetentie een min of meer centrale plaats innemen. Bij wijze van voorbeeld zal de interculturele competentie een centrale rol vervullen bij het vertalen van een tekst over de $\mathrm{Ne}$ derlandse en Vlaamse nationale identiteit. Deze competentie zal eveneens van belang zijn voor het vertalen van een wetenschappelijke tekst over bijvoorbeeld de zwaartekracht, hoewel de rol ervan ervan minder doorslaggevend zal zijn.

\subsection{Componenten vertaalcompetentie}

Zoals reeds aangestipt in punt 2.1. en 2.3. kunnen we talrijke modellen onderscheiden voor de omschrijving van de vertaalcompetentie, gaande van minimalistische modellen (zoals bijvoorbeeld het minimalistic model van Anthony Pym) tot multicomponentiële modellen (zoals bijvoorbeeld het model van Allison Beeby dat hierna zal worden besproken). Deze modellen zijn geconstrueerd op basis van wetenschappelijke bevindingen van academici en worden door universiteiten als blauwdruk gebruikt bij het ontwerpen van vertaalcursussen.

Bij de ontwikkeling van deze modellen speelden telkens verschillende factoren of componenten een rol, die werden gedefinieerd op basis van empirische data of werden ontleend uit verschillende vakgebieden of disciplines. Een voorbeeld 
van zo'n multicomponentieel model is dat van Allison Beeby dat in 2003 door de onderzoeksgroep PACTE werd vooropgesteld (zie Figuur 1). Volgens dit model dat een herziene versie is van het model dat in 1998 werd ontworpen, bestaat de vertaalcompetentie uit vijf subcompetenties en activeert ze bovendien een reeks psycho-fysiologische mechanismen (zie nr. 6: psycho-fysiologische componenten). Deze subcompetenties zijn:

1. tweetaligheidssubcompetentie (bilingual sub-competence): deze competentie heeft betrekking op de procedurele kennis die nodig is om in beide talen te communiceren, en omvat de pragmatische, sociolinguïstische, tekstuele, grammaticale en lexicale kennis in beide talen (PACTE 2003: 57);

2. extra-lingusitische subcompetentie (extra-linguistic sub-competence): Deze competentie betreft voornamelijk kennis - zowel impliciete als expliciete - met betrekking tot de wereld en een of meerdere specialisatiegebieden. Het omvat: (1) biculturele kennis (of kennis van de bron- en doelcultuur); (2) encyclopedische kennis (of algemene wereldkennis); (3) vakkennis (of kennis van een of meerdere specialisatiegebieden) (PACTE 2003: 57);

3. subcompetentie m.b.t. vertaalkennis (knowledge about translation sub-competence): deze vaardigheid verwijst hoofdzakelijk naar kennis - zowel impliciete en expliciete - over de betekenis van vertalen en houdt verder ook verband met de kennis van de specifieke aspecten van het beroep van vertaler. Het omvat: (1) de kennis over hoe een vertaling functioneert: soorten vertaaleenheden, vereiste processen, toegepaste methoden en procedures (strategieën en technieken) en soorten vertaalproblemen; (2) de kennis met betrekking tot de professionele vertaalpraktijk: kennis van de arbeidsmarkt (soorten opdrachten, klanten en publiek, etc.) (PACTE 2003: 57);

4. instrumentele subcompetentie (instrumental sub-competence): deze competentie houdt verband met de procedurele kennis m.b.t. het gebruik van bronnen en informatie- en communicatietechnologieën toegepast op de vertaling: allerlei soorten woordenboeken, encyclopedieën, grammatica's, stijlboeken, parallelle teksten, elektronische corpora, zoekmotoren, etc. (PACTE 2003: 58);

5. strategische subcompetentie (strategic sub-competence): deze subvaardigheid verwijst naar de procedurele kennis die vereist is om de effectiviteit van het vertaalproces te garanderen en om ervaren moeilijkheden op te lossen. Omdat deze subcompetentie een centrale rol vervult in het vertaalproces en er toezicht op uitoefent, beïnvloedt zij op aanzienlijke wijze alle andere subcompetenties en creëert zij er banden tussen. Dit komt goed tot uiting in de onderstaande figuur 1 van de onderzoeksgroep PACTE (2003). ${ }^{3}$

\footnotetext{
${ }^{3}$ Het model voor de vertaalcompetentie (TC model) van de onderzoeksgroep PACTE werd voor het eerst gepresenteerd in 1998 en later in 1998, 2000 en 2001. In 2003 werd het model herzien in het licht van de resultaten van een onderzoek verricht in 2000 (PACTE 2003).
} 
Tot de functies van de strategische subcompetentie behoren: (1) de planning en uitvoering van een vertaalproject (keuze van de meest geschikte methode); (2) de evaluatie van het vertaalproces en van de bereikte resultaten met betrekking tot het uiteindelijke vertaaldoel; (3) het activeren van de verschillende deelcompetenties en het compenseren van hun tekortkomingen; (4) het identificeren van vertaalproblemen en het toepassen van geschikte procedures om deze op te lossen (PACTE 2003: 58);

6. psycho-fysiologische componenten (psycho-physiological components): deze componenten houden verband met verschillende types van cognitieve- en houdingscomponenten en psychomotorische mechanismen. Zij omvatten: (1) cognitieve componenten zoals geheugen, perceptie, aandacht en emoties); (2) houdingsaspecten zoals intellectuele nieuwsgierigheid, doorzettingsvermogen, nauwkeurigheid, kritische geest, kennis van en vertrouwen in eigen capaciteiten, het vermogen om eigen capaciteiten te meten, motivatie, etc.; (3) vaardigheden zoals creativiteit, logisch redeneren, analyse- en synthesevermogen, enz.

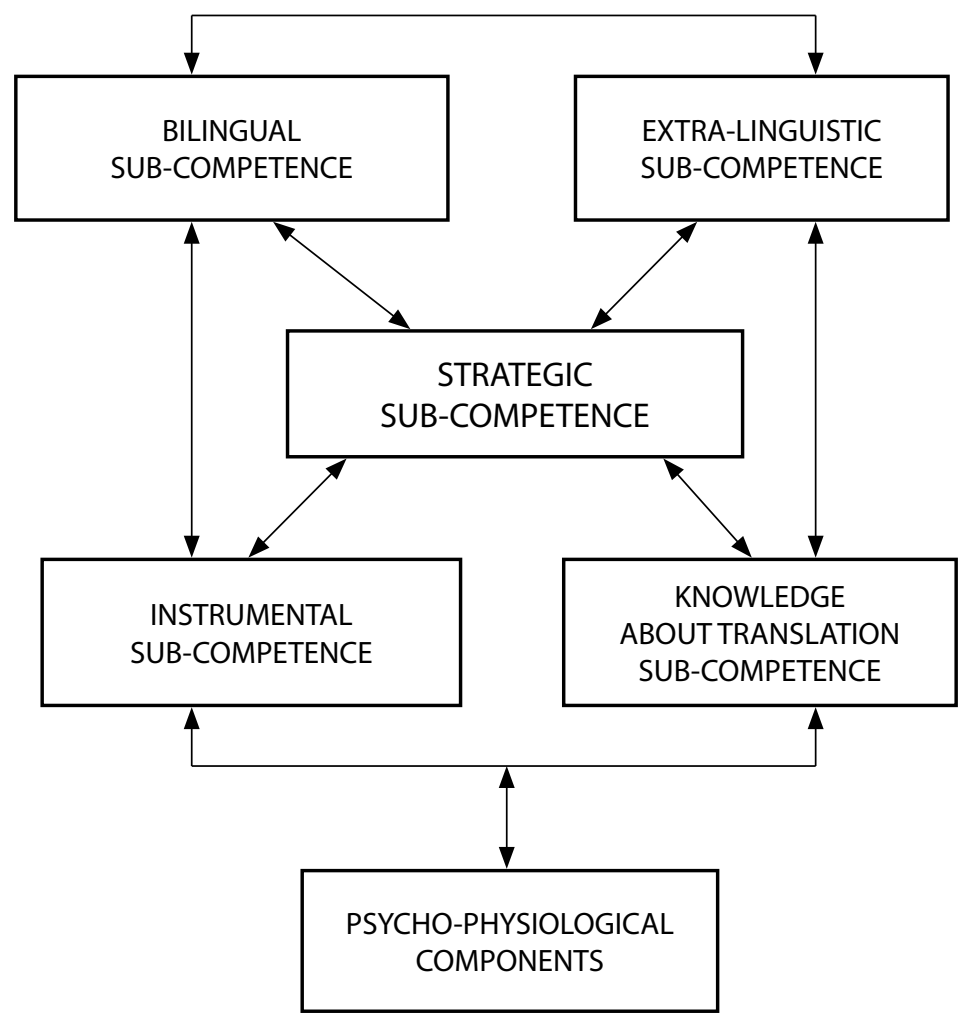

Fig. 1. Model vertaalcompetentie (herzien) (PACTE group 2005: 610) 
De bovengenoemde subcompetenties zijn op elk ogenblik onderhevig aan variatie en bewegen zich binnen de overkoepelende vertaalcompetentie. We hebben hier dus te maken met een dynamische kijk op deze competentie.

In haar model (cfr. Figuur 1) verwijst Beeby niet expliciet naar de term interculturele competentie maar naar een extra linguistic competence. Dit is de enige subcompetentie die enigszins in verband kan worden gebracht met het aspect cultuur, omdat het de kennis van de wereld betreft, waar de zogenaamde biculturele kennis deel van uitmaakt. Wanneer we de inhoud van deze component vergelijken met die van de componenten van het model van Michael Byram dat voor interculturele competentie vooropgesteld wordt door het Gemeenschappelijk Europees referentiekader (ERK), zien we dat de inhoud van Beeby's extra linguistic competence overeenkomt met de inhoud van de component dat in Byram's model wordt gedefinieerd als savoirs, omdat het ook vooral verband houdt met cognitieve kennis. Byram heeft het echter wel specifiek over de kennis van verschillende sociale groeperingen en hun producten en praktijken in eigen land en in dat van de gesprekspartner of de kennis van de cultuur van eigen land en van dat van de gesprekspartner. Vermoed wordt dat dit de reden is waarom deze component bij Beeby de naam interculturele competentie niet draagt, doordat de term wereldkennis door haar in ruimere zin wordt opgevat.

Naast de bovengenoemde savoirs beschrijft Byram nog vier andere elementen die de taalspreker intercultureel competent en die we kunnen toepassen op de context van vertalen: ${ }^{4}$

- savoir comprendre of de vaardigheid in het interpreteren en plaatsen van documenten of gebeurtenissen uit andere culturen;

- savoir apprendre/faire of de vaardigheid in het ontdekken van elementen van een andere cultuur en daar op te reageren;

- savoir être of de vaardigheid om een open en nieuwsgierige houding aan te nemen ten aanzien van andere culturen en de bereidwilligheid om het oordeel over de eigen cultuur en die van de ander te nuanceren;

- savoir s'engager of het vermogen om kritisch te kijken naar verhoudingen, praktijken en producten, zowel in eigen land en cultuur als in vreemde culturen, zich daarbij baserend op expliciete beoordelingscriteria.

De bovengenoemde savoirs kunnen direct gekoppeld worden aan de competenties die een hedendaagse vertaler dient te bezitten. Het vertaalproces is nooit louter een kwestie van een betekenisoverdracht van de ene naar de andere taal, maar is altijd gerelateerd aan het 'vertalen' van de ene cultuur naar de andere.

\footnotetext{
${ }^{4}$ De toepassing van de systematiek van het ERK (waar interculturele communicatie als belangrijk doel wordt vooropgesteld) op vertalen is internationaal geaccepteerd. Een voorbeeld hiervan is de toepassing ervan voor de ontwikkeling van de Leerlijn Literair Vertalen (zie: http://literairvertalen. org/nieuwsbrief/juni_2014: geraadpleegd op 30.12.2015).
} 
Daarom is het belangrijk dat de interculturele competentie van toekomstige vertalers systematisch wordt ontwikkeld.

\section{Het 'model Van Kalsbeek' toegepast op de vertaaldidactiek}

Wanneer we een blik werpen op de inhoud van Byram's vijf savoirs die ontwikkeld moeten worden om een vertaler intercultureel competent te maken, zien we dat er naast de savoirs of cognitieve kennis nog vier andere savoirs ontwikkeld moeten worden die verband houden met aspecten van gedrag en affect (gevoel). Die savoirs zijn gewoonlijk moeilijker aan te leren. Omdat ons toekomstig project ook het trainen van dit soort savoirs beoogt, deed ik voor de uitwerking van de pedagogische aanpak beroep op het door Alice van Kalsbeek (2003: 91) voorgestelde didactische model voor het trainen van dit type savoirs in het vreemdetaalonderwijs (zie Tabel 1) en paste het toe op het vertaalonderwijs. Aan de grondslag van haar model vinden we drie kernbegrippen Openness, Knowledge, Adaptibility terug die Byram (1997) en Holliday et al. (2004) hanteren om de basis van interculturele competentie te omschrijven. Daar komt volgens Van Kalsbeek nog een vierde kernbegrip aan toe, met name de Critical Awareness of het kritische bewustzijn.

Volgens Van Kalsbeek verwijzen Byram's savoirs naar algemene competenties die elke interculturele communicator nodig heeft om te kunnen functioneren als een intercultureel competente individu (cfr. in het Engels: intercultural individual). Ze onderscheidt deze competenties van de beroepsgerichte competenties die een taalleerder - en in ons geval een vertaler - moet verwerven om op de werkvloer te kunnen functioneren als een intercultureel persoon (cfr. intercultural being). In de context van het beroep van vertaler houdt dit verband met competenties die specifiek gericht zijn op het functioneren in het werkgebied van een vertaler. Net als in het geval van een NT2-taalleerder, gaat het hier om competenties waarover ook de (vertaal)docenten moeten beschikken om die te kunnen overbrengen aan hun leerders.

Van Kalsbeek (2003: 91) stelt vast dat in de didactiek van een geïntegreerd taal- en cultuuronderwijs drie begrippen regelmatig naar voren komen: perspectief, context en dialoog. Deze drie begrippen verwijzen naar werkvormen die bijdragen tot de culturele bewustwording, de kennis over andere culturen (de doelcultuur), de ontwikkeling van interculturele vaardigheden. We kunnen ze beschouwen als een soort van 'geleiders' om interculturele competentie te verwerven. Bij de integratie van al deze fundamentele begrippen, komt Van Kalsbeek (2008: 2) tot het volgende schema: 
Tabel 1. Schematische voorstelling didactiek van een geïntegreerd taal- en cultuuronderwijs (Van Kalsbeek 2008: 2)

\begin{tabular}{lccc}
\hline Algemeen & Openness & $->$ & Attitude \\
Knowledge & $->$ & Knowledge \\
Adaptability & $->$ & Skills \\
Beroepsgericht & Perspective & $->$ & Attitude \\
& Context & $->$ & Knowledge \\
& Dialogue & $->$ & Skills \\
\hline
\end{tabular}

Aan de hand van dit schema kunnen docenten lesmateriaal ontwikkelen dat leerders (en in ons geval vertalers) niet alleen communicatief competent maakt, maar ook intercultureel competent, door de bewustwording van de eigen attitude ten opzichte van andere culturen, het vergroten van kennis over de te leren cultuur en het ontwikkelen van interculturele vaardigheden (Van Kalbeek 2003: 91).

Voor het toetsen van interculturele competentie suggereert Byram (1997: 106) om gebruik te maken van een portfolio. Hij acht dat zelfs wenselijk, omdat zo het beste de ontwikkeling van interculturele competentie zichtbaar wordt. ${ }^{5}$ Een portfolio is namelijk een nuttig instrument in het proces van lifelong learning, waar iedere professional tegenwoordig mee te maken heeft. Het zogenaamde Europese Taalportfolio (ELP) werd door de Raad van Europa trouwens gecreëerd als belangrijk tweede instrument van toepassing, naast het Europees Referentiekader (CEF) voor Talen, om op een snelle manier het juiste niveau van een gebruiker zonder veel bijkomende proeven in te schatten (Catteeuw en Coutuer 2005: 16). Innoverend hierbij is dat naast officiële bewijzen zoals diploma's en certificaten, ook gegevens over informeel leren kunnen worden opgenomen. Portfolio's vormen een belangrijk onderdeel van de door in 2005 ingevoerde Europass waar ze kunnen worden opgenomen om vaardigheden en competenties te documenteren met het oog op studie of werk in Europa. ${ }^{6}$ Het portfolio is dus een instrument dat (eerder en elders) verworven competenties documenteert en bewijst aan de hand van documenten, reflectie en feedback.

Wat voor ons van belang is, is dat portfolio's verschillende functies kunnen hebben, afhankelijk van het doel waarvoor het gebruikt wordt. Ze kunnen worden gebruikt door leerders om eigen vooruitgang op te volgen, door docenten om

\footnotetext{
${ }^{5}$ De Raad van Europa ontwikkelde eind jaren 1990 een Europees Taalportfolio (ELP) dat werd gelanceerd tijdens het Europese Jaar van de Talen (2001) om in Europa de meertaligheid en het multiculturalisme te bevorderen. Aan de basis ligt de ontwikkeling van het Common European Framework of Reference for Languages (CEF), het Europees Referentiekader voor Talen dat vanaf het begin van de jaren 1990 vorm kreeg.

${ }_{6}^{6}<$ http://europass.cedefop.europa.eu/nl/home> (geraadpleegd op 15.05.2015).
} 
hun studenten te volgen, te begeleiden en formatieve of verbeterende ${ }^{7}$ feedback te geven. Daarnaast kunnen ze ook worden aangewend voor summatieve doeleinden d.i. als beoordelingscriteria of om onderwijsdoeleinden te meten. Een dergelijke teaching portfolio kan competenties betreffen van didactiek, interculturele communicatie, organisatie en beroepsgerichte taalvaardigheid, ${ }^{8}$ het kan dus ook worden bijgehouden door vertaaldocenten die hun leerders willen opleiden tot intercultureel competente vertalers. Het biedt ook ruimte voor onder meer de omschrijving van werkvormen die tijdens vertaalcolleges kunnen worden gehanteerd om de geleiders 'perspectief,' 'context' en 'dialoog' in het vertaal(leer) proces te stimuleren en bijgevolg de attitude, kennis en vaardigheden van de leerders in de beroepscontext te optimaliseren. Net zoals Van Kalsbeek (2003: 91) deze methode toepaste voor het vreemdetaalonderwijs kan die door vertaaldocenten worden aangewend in het vertaalonderwijs en kunnen werkvormen worden bedacht voor het stimuleren van de drie geleiders 'perspectief,' 'context' en 'dialoog.'

\subsection{Perspectief}

Deze geleider houdt verband met de bewustwording van eigen attitude ten opzichte van andere culturen als noodzakelijk element om de interculturele competentie van de leerder te bevorderen. Mensen zien steeds wat ze willen zien en interesseert, wat hun 'schemata' of 'frames' ze ingeven. 'Frames' of 'schemata' zijn algemene structuren in taal en cultuur die mensen in hun hoofd hebben (Van Kalsbeek 2003: 91). Ze bepalen in belangrijke mate de waarneming van mensen die reageren en handelen vanuit een aantal preconcepties. In onderwijsverband komt het er in dit stadium op neer om de voorkennis van een leerder te mobiliseren om te ontdekken wat zijn of haar preconcepties zijn en waar die moeten worden bijgesteld. In de context van vertalen, betekent dit onder meer dat de leerder het perspectief ontdekt van waaruit een tekst werd geschreven en in staat is om een ander perspectief aan te nemen. Dit aspect kan in verband worden gebracht Byram's savoir être.

Bij alle leerprocessen, ook bij vertaling is het belangrijk om aan te sluiten bij reeds aanwezige kennis en vaardigheden. Werkvormen die geschikt zijn voor het mobiliseren van voorkennis zijn onder andere brainstormen en vragen stellen. Bij aanvang van de vertaling van een bepaald tekstgenre (reclametekst, toeristische brochure, juridische tekst, gebruiksaanwijzing e.d.m.) kan aan de leerders bijvoorbeeld worden gevraagd naar hun eventuele ervaring in het vertalen van zo'n teksten, wat specifiek is aan dit tekstgenre en waar ze denken rekening

\footnotetext{
${ }^{7}$ Formatieve/verbeterende feedback zal een invloed hebben op de kwaliteit van het gedrag. Deze feedback wil het huidige gedrag veranderen in het gewenste gedrag.

${ }^{8}<$ http://www.snvt.org/projecten/project.html?id=11> (geraadpleegd op 14.03.2015).
} 
mee te zullen moeten houden bij het vertalen van dit tekstgenre. Verder kan ook worden gedacht aan een vraagstelling vanuit het dubbel perspectief (Pinto 1990) die erop neerkomt dat de leerder het perspectief probeert aan te nemen van bijvoorbeeld de doelcultuur waarvoor de te vertalen tekst bestemd is.

\subsection{Context}

De geleider 'context' houdt verband met het vergroten van de cognitieve kennis over de doelcultuur van de leerders en verwijst naar Byrams savoirs. Studenten kunnen hier bijvoorbeeld de taak krijgen om zelf de context van de te vertalen tekst te construeren door samen informatie over het onderwerp van de tekst te zoeken en kennis over het onderwerp uit te wisselen. Het internet kan hier als nuttige bron van informatie dienen.

\subsection{Dialoog}

Ook via deze geleider wordt de ontwikkeling van de interculturele competenties van de leerder beoogd. Claire Kramsch (1993) stelt in deze context de dialogische pedagogiek voorop voor geïntegreerd taal-en cultuuronderwijs. Groepswerk is volgens haar de beste manier om dialogische pedagogiek te realiseren. Door samen opdrachten uit te voeren krijgen leerders inzicht in elkaars culturele bagage. Volgens Kramsch kan daar zelfs een derde cultuur geschapen worden waar concepten een nieuwe betekenis krijgen.

Een dergelijke aanpak kan ook worden toegepast tijdens vertaalcolleges. In de onderwijspraktijk komt het erop neer om in lessituaties studenten via een dialogische pedagogiek aan te zetten tot reflectie over hoe vertaalproblemen kunnen worden opgelost om interculturele miscommunicatie te voorkomen. Dit houdt verband met Byram's savoir apprendre/comprendre.

Uiteidelijk zullen deze drie 'geleiders' helpen het kritisch cultureel bewustzijn - het zogenaamde savoir s'engager - van de intercultureel competente vertaler te ontwikkelen.

\section{Het KUL Johannes Paulus II-vertaalproject (KUL JPII-project) in spe}

\subsection{Aanvang samenwerking met vereniging van vertalers}

Dit academiejaar heeft een Poolse vereniging van Nederlandse, Poolse en Vlaamse professionele en beëdigde vertalers ons voorgesteld om gratis workshops te bezorgen aan de studenten van onze Leerstoel. ${ }^{9}$ Tijdens de eerste workshop

${ }^{9}$ Zie https://freeling20150226.konfeo.com/pl/groups (geraadpleegd op 23.05.2015) voor meer informatie over deze workshop. 
die in februari 2015 heeft plaatsgevonden, werd vooral aandacht besteed aan de transcriptie van eigennamen en de vertaling van korte fragmenten uit allerlei gespecialiseerde teksten (juridische, financiële, zakelijke, administratieve e.d.m.). Uit deze ervaring is gebleken dat dit soort vertaaloefeningen vooral geschikt is voor studenten die zich in de masterfase van hun opleiding bevinden. Bovendien hebben we kunnen ondervinden dat studenten in de bachelorfase van hun studie geen of weinig ervaring hebben met het vertalen van teksten naar het Nederlands, en dat ze er meer nut van zouden hebben om eerst een dieper inzicht te verkrijgen in 'de procedure van aanpak' die moet garanderen dat ze de juiste vragen stellen vooraleer ze aan de slag gaan met vertalen. Deze reflectie kan meer worden gestimuleerd door ervoor te kiezen om te werken met de vertaling van teksten die culturele referenties ${ }^{10}$ en realia ${ }^{11}$ bevatten, en die voor een specifieke doelgroep (Nederlanders, Vlamingen of Polen) moeten worden vertaald. Op die manier wordt de leerder er zich van bewust dat vertalen een soort van handelen en beslissen is, en dat het eigenlijk deel uitmaakt van een intercultureel communicatieproces. Enkel op die manier kan de leerder zich meer bewust gaan worden van de eigen en de vreemde cultuur en worden opgeleid tot een intercultureel competente vertaler.

Vandaar dat we besloten het theoretische en praktische kader van de samenwerking met deze vereniging uit te diepen. In de eerste fase zou dat gebeuren voor de bacheloropleiding die als basis kan dienen voor het KUL JPII-vertaalproject dat beoogt effectief bij te dragen tot het intercultureel bewustzijn van de leerders via vertaalcolleges. In wat volgt wordt bondig ingegaan op deze theoretische en praktische achtergronden van het project.

\subsection{Theoretisch kader (didactische aanpak) van het KUL JPII- vertaalproject}

Zoals reeds aangestipt situeert ons vertaalproject zich in het kader van de functionele aanpak van de vertaaldidactiek zoals gedefinieerd door Justa Holz-Mänttäri (Schäffner 2003: 89) waarbij vertaling wordt gezien als een daad van interculturele communicatie (Sondersorte interkultureller Kommunikation) in plaats van een vaardigheid in het overdragen van minimale linguïstische eenheden over de taalgrenzen heen (Vermeer 1998: 61). Deze aanpak heeft directe en verstrekkende

\footnotetext{
${ }^{10}$ Met de term culturele referenties wordt verwezen naar tekstuele elementen die cultuurgebonden zijn en "waarvoor de brontaal en doeltaal geen vanzelfsprekende culturele equivalentie delen" (Jooken 2004: 54).

${ }^{11}$ De term realia (dingen uit de werkelijkheid) is afkomstig van de Russische vertaalwetenschap waar hij staat voor "woorden (en collocaties) die verwijzen naar objecten, concepten en fenomenen die typisch zijn voor de geografische omgeving, de cultuur, het dagelijkse leven of de sociaal-historische eigenheid van een bepaald volk, natie, land of stam, en als zodanig bijdragen tot de lokale of historische kleuring; zulke woorden hebben geen equivalent in andere talen" (Vanderweghe 2005: 39).
} 
gevolgen voor het onderwijs van de vertaling, omdat vertaling neerkomt op de productie van een tekst voor specifieke ontvangers in een specifieke context of 'actiekader' (Handlungsrahmen) die bestaat uit een aantal onderlinge afhankelijke factoren, zoals de situatie, de communicatieve functie van een tekst (Vermeer 1989), de opdrachtgever (Auftraggeber), de zender, de ontvanger(s) etc. In het kader van deze aanpak beweegt de inhoud van een tekst zich niet langer van één taal naar een andere taal maar van een context naar een andere context.

De leermethode berust op het uitvoeren van een functionele taak die verstrekt wordt door een opdrachtgever. Volgens Nord wordt van de vertaler verondersteld dat hij optreedt als een expert in interculturele communicatie, waarbij hij de doelen, verwachtingen en werkomstandigheden van de opdrachtgever analyseert en handelt als een cultureel adviseur (Nord 2005: 31). Tijdens de lespraktijk dient dit soort interactie te worden gesimuleerd.

Naast de theorie van Holz-Mänttäri, wordt in het project ook gebruik gemaakt van de pedagogische inzichten van Claire Kramsch (1993). Kramsch (1993: 208) beschouwt cultuur als "a social construct, the product of self and other perceptions." Cultuur ziet zij als een sociaal product, als de resultante van interactie tussen mensen, dus als een continu creatief proces. Als mensen met elkaar in contact zijn, binnen culturen en tussen culturen, is die cultuur in beweging. Daardoor is het volgens haar zo moeilijk om cultuur geïsoleerd over te dragen. Volgens Kramsch komt in de dialoog en in gesprekken de interactie tussen tekst en context en tussen verschillende interpretaties van tekst en context aan de orde. Ze propageert de dialogische pedagogiek voor geïntegreerd taal- en cultuuronderwijs. Deze pedagogiek willen we toepassen in vertaalcolleges, onder meer via het invoeren van taken die in groepswerk (pairwork) worden gerealiseerd, waardoor leerders (en zoals we verder zullen zien in een later stadium van het project leerders en professionele vertalers in gesprek gaan met elkaar en met professionele vertalers, wat hen toelaat hun crossculturele bagage te verrijken om intercultureel competent te worden. Dankzij deze theorie kan dit worden bewerkstelligd, doordat de nadruk van het leerproces bestaat uit het oplossen van functionele problemen in tekstreceptie en -productie, en de taak van de docent neerkomt op het suggereren van strategieën en het begeleiden en bespreken van het individueel en groepswerk verrichte onderzoek (Vermeer 1998: 62).

\subsection{Praktische uitwerking van het KUL JPII-vertaalproject}

Zoals reeds aangestipt in punt 4.2.1. zou in de bacheloropleiding in het bijzonder aandacht worden besteed aan de vertaling van teksten die culturele referenties en realia bevatten. Volgens Gonzalez Davies en Scott-Tennent (2005: 166) wordt in het vertaalonderwijs namelijk te weinig aandacht besteed aan deze problematiek. Om tegemoet te komen aan deze lacune, zal in het vertaalproject aandacht worden 
besteed aan dit aspect door te werken rond de vertaling van teksten over culturele onderwerpen zoals instellingen van het land, cultuurgeschiedenis, zeden en gewoonten, tradities, beeldende kunst, muziek, media, literatuur. Elke soort tekst heeft zijn specificiteit. Anderzijds zouden ze ook pragmatische en instructieve teksttypes te vertalen krijgen zoals advertenties, websites, instructies e.d.m.

Wat de praktische uitwerking van het project betreft, zouden de leerders tijdens een academiejaar werken rond vier modules of opdrachten die elk gericht zijn op de vertaling van een brontekst bestemd voor een specifieke doelgroep (Polen, Nederlanders of Vlamingen). Elke module of opdracht zou vier weken in beslag nemen en in de vijfde week afgerond worden met een workshop georganiseerd in samenwerking met de vereniging.

Wat de inhoud van de praktische vertaalcolleges betreft ${ }^{12}$ zouden de studenten tijdens week 1 informatie krijgen over de wetenschappelijke literatuur rond vertalen en vertaaltools waarvan ze kennis moeten nemen. Op die manier leren de leerders naslagwerken en internet effectief te gebruiken om de juiste vertaling en passende formulering te vinden. Bovendien zou de opdrachtgever (d.i. de vereniging zonder winstoogmerk) hun een te vertalen tekst bezorgen uit de beroepspraktijk en hun informatie verstrekken over de doelgroep (uit Polen, Nederland of Vlaanderen).

De tweede week bereiden de studenten de vertaling in groepjes van twee (pairs) voor: dit houdt in dat ze vertaalproblemen (waaronder realia) aanduiden en de nodige vertaalkeuzes maken: opteren ze voor een bron- of doeltekstgerichte vertaling, kiezen ze voor een letterlijke of vrije vertaling van de tekst? Deze didactische aanpak confronteert studenten met 'nieuwe' problemen en nodigt hen uit hiervoor een eigen oplossing te formuleren.

De derde week presenteert elke groep zijn oplossingen voor vertaalproblemen en keuzes aan de andere studenten: via groepsdiscussies leren studenten vertalingen kritisch te beoordelen. Daarna selecteert elke groep de beste vertaling aangepast aan de doelgroep (doelcultuur) waarvoor ze vertalen. Tot slot wordt de volledige tekst tijdens de (derde en) vierde week vertaald en worden de vertalingen aan de vereniging bezorgd.

Tijdens de vijfde week ontmoeten de studenten de professionele vertalers voor een workshop. Tijdens die workshop houden een of twee groepen (pairs) een korte uiteenzetting over de specifieke vertaalproblemen die ze zijn tegengekomen tijdens het vertalen van de tekst, over de beslissingen die ze hebben genomen bij het vertalen van hun tekst naar de doelcultuur. Ze dienen daarbij de keuze van de terminologie te staven aan de hand van neventeksten, contexten of definities en een eigen bestand te maken met geëigende bronnen.

${ }^{12}$ De gehanteerde werkmethode berust voor een deel op die van Isabelle Peeters in haar project Kunstenfestivaldesarts (Peeters 2013). 
Na de presentaties krijgen de groepen van de Auftraggeber feedback op hun vertaling. Dit gebeurt in de vorm van een discussie en op basis van een vergelijking van hun vertalingen met die van een (Poolse, Vlaamse en/of Nederlandse) beroepsvertaler. Tijdens de workshop wordt daarnaast nog in het bijzonder aandacht besteed aan verschillen tussen Nederland en Vlaanderen in terminologie, syntaxis, tekstopbouw etc. Dit gebeurt aan de hand van korte vertaaloefeningen.

\section{Conclusie: meerwaarde van het project?}

De meerwaarde van dit project is meervoudig. Een van de belangrijkste voordelen ervan is dat de leerder centraal staat en de docent begeleider wordt in het leerproces. Een tweede pluspunt bestaat erin, dat de door Byram gedefinieerde vijf savoirs worden geactiveerd via de drie geleiders 'perspectief,' 'context' en 'dialoog.' De eerste geleider 'perspectief' wordt gestimuleerd doordat de leerder wordt aangezet om een ander perspectief aan te nemen, met name die van de nieuwe initiator of zender die de compatibiliteit tot stand moet brengen tussen brontekstintentie en doeltekstfunctie.

Via de geleider 'context' worden de leerders aangezet om op zoek te gaan naar informatie over het onderwerp van hun vertaling in de doelcultuur (bijvoorbeeld in een tekst over instellingen of zeden en gewoonten) en die met elkaar uit te wisselen tijdens de colleges. Op die manier verrijken ze hun cognitieve kennis over de doelcultuur.

Tot slot wordt de geleider 'dialoog' ingezet doordat aan de hand van een dialogische aanpak de studenten hun eigen culturele bagage verrijken via gesprekken met andere studenten en beroepsvertalers.

Een laatste pluspunt van het project is dat de leerders in een semi-professionele context werken, waarin hun motivatie wordt gestimuleerd, waarin ze worden aangezet tot het vergaren van juiste informatie, tot het nemen van beslissingen en risico's en tot het oplossen van problemen. Hiermee rekening houdend hopen we dat dit project ertoe zal bijdragen dat onze studenten uitstekende interculturele mediatoren worden in de vertaalwereld.

\section{Bibliografie}

Beeby, A. 2000. "Choosing an Empirical-Experimental Model for Investigating Translation Competence: The PACTE Model." Intercultural Faultiness. Research Models in Translation Studies I. Textual and Cognitive Aspects. Manchester: St Jerome.

Bell, R.T. 1991. Translation and Translating. Theory and Practice. London/New York: Longman. 
Byram, M. 1997. Teaching and Assessing Intercultural Communicative Competence. Clevedon: Multilingual Matters.

Catteuw, P., en M. Coutuer. 2005. “Een portfolio voor interculturele competenties. Zoektocht naar een referentiekader interculturele communicatie." Mores 6: 15-20. 23 May 2015. <http://www.prosper.ro/EuroIntegrELP/materiale\%20pentru\%20site\%20EuroIntegrELP_12\%20sept/Articles/NL_KdG_Article_Mores.pdf>.

Deardorff, D.K. 2006. "Identification and Assessment of Intercultural Competence as a Student Outcome of Internationalization of Higher Education in the United States." Journal of Studies in International Education 10(3): 241-266.

2008. "Intercultural Competence. A Definition, a Model, and Implications for Education Abroad." Developing Intercultural Competence and Transformation. Theory, Research, and Application in International Education. Ed. Victor Savicki. Sterling, Virginia: Stylus Publishing, LLC. 32-52.

“Europass." z.d. 15 May 2015. <http://europass.cedefop.europa.eu/nl/home>.

Eyckmans, K., en W. Segers. 2010. "Systematische verwerving van zoekcompetentie." Tolk- en vertaalcompetentie. Onderwijs- en toetsvormen. Eds Winibert Segers, en Chris Van de Poel. Leuven/Den Haag: Acco. 89-94.

"Gemeenschappelijk Europees Referentiekader voor Moderne Vreemde Talen: Leren, Onderwijzen, Beoordelen." 2013. 2 Apr. 2015. <http://taalunieversum.org/publicaties/ gemeenschappelijk-europees-referentiekader-voor-moderne-vreemde-talen-lerenonderwijzen->.

Gonzalez Davies, M., C. Scott-Tennent. 2005. “A Problem-Solving and Student-Centred Approach to the Translation of Cultural References." Meta 50(1): 160-179.

Holliday, A., M. Hyde, en J. Kullman. 2004. Intercultural Communication. An Advanced Resource Book. London/New York: Routledge Applied Linguistics.

Jooken, L. 2004. "'Impossible to translate, Arno. Dutch is a secret language, you know." De vertaling van culturele referenties in All Souls' Day." Taal en cultuur in vertaling. De wereld van Cees Noteboom. Eds S. Evenpoel et al. 53-67.

Kalsbeek, A. van. 2003. " Taal en cultuur of cultuur en taal?" Cultuur in taal. Interculturele vaardigheden voor docenten Nederlands aan anderstaligen. C. van Baalen, L. Beheydt, en A. van Kalsbeek. Utrecht: ncb. 61-102.

2008. "Intercultural competences for Foreign Language Teachers." 2 Feb. 2015. <http://intt.uva.nl/binaries/content/assets/subsites/institute-for-dutch-as-a-second-language/map-1/interculturele-competenties-in-het-nt2-onderwijs-auteurskwaliteiten-of-docentvaardigheden.pdf $>$.

2010. "Cultuur in het onderwijs Nederlands als tweede taal: auteurskwaliteiten of docentvaardigheden?" Klassiek Vakwerk II. Achtergronden van de NT2-lespraktijk: lezingen conferentie Hoeven 2010. Ed. B.H. Bossers. Amsterdam: VU Reprografie. 193-203.

Kramsch, C. 1993. Context and Culture in Language Teaching. Oxford: Oxford University Press.

Meijer, D., en J. Noijons. 2008. Gemeenschappelijk Europees Referentiekader voor Moderne Vreemde Talen: Leren, Onderwijzen, Beoordelen. Den Haag: Nederlandse Taalunie.

Nord, C. 2005. Text Analysis in Translation: Theory, Methodology, and Didactic Application of a Model for Translation-oriented Text Analysis. $2^{\text {nd }}$ revised edition. Amsterdam-New York: Rodopi. 
PACTE. 2003. "Building a Translation Competence Model." Triangulating Translation: Perspectives in Process Oriented Research. Ed. F. Alves, F. Amsterdam: John Benjamins Publishing Co. 43-66.

PACTE group. 2005. "Investigating Translation Competence: Conceptual and Methodological Issues." Meta 50(2): 609-619.

"PACTE research group". z.d. 22 Apr. 2015. <http://grupsderecerca.uab.cat/pacte/en>.

Peeters, I. 2003. "Comment optimiser la compétence (inter)culturelle des étudiants en traduction: un projet authentique prometteur." Babel. Revue Internationale de Traduction / International Journal of Translation 59(3). Amsterdam: John Benjamins Publishing Co. 257-273.

Pinto, D. 1990. Interculturele communicatie. Drie-stappenmethode voor het doeltreffend overbruggen en managen van cultuurverschillen. Houten/Zaventem: Bohn Stafleu Van Loghum.

“Portfolio voor docenten Nederlands als vreemde taal." z.d. 14 March 2015. <http:// www.snvt.org/projecten/project.html?id=11>.

Pym, A. 2003. "Redefining Translation Competence in an Electronic Age. In Defence of a Minimalist Approach." Meta 48(4): 481-497.

Schäffner, C. 2003. "Translation and Intercultural Communication: Similarities and Differences." Studies in Communication Sciences 3(2): 79-107.

Vanderweghe, W. 2005. Duoteksten. Inleiding tot vertaling en vertaalstudie. Gent: Academia Press.

Vermeer, H.J. 1989. "Skopos and Commission in Translational Action." Readings in Translation Theory. Ed. Andrew Chesterman. Helsinki: Oy Finn Lectura Ab. 173-187. 1998. "Didactics of Translation." The Routledge Encyclopedia of Translation Studies. Ed. Mona Baker. London/New York: Routledge. 60-62.

"Warsztaty translatorskie dla studentów - Lublin - 26.02.2015." z.d. 23 May 2015. $<$ https:// freeling20150226.konfeo.com/pl/groups, geraadpleegd op 23.05.2015>.

Wilss, W. 1976. "Perspectives and Limitations of a Didactic Framework for the Teaching of Translation." Translation. Applications and Research. New York: Gardner Press. 117-137. 